\title{
Effect of privatization and broader reforms on the labour use adjustments and efficiency
}

\author{
Yaseen Ghulam a,b \\ a. University of Portsmouth, Portsmouth Business School, \\ Economics and Finance Subject Group \\ Richmond Building, Portland Street, PO1 3DE, UK \\ Email: yaseen.ghulam@port.ac.uk \\ Phone: +442392844127 \\ b. Al Yamamah University 7010 King Fahd Road, \\ Al Qirawan, Riyadh 13541, Saudi Arabia
}




\title{
Effect of Privatization and Broader Reforms on Labour Use Adjustments and Efficiency
}

\begin{abstract}
State owned firms were said to have an excessive use of labour. The cost of job losses after privatization was debated but ignored due to perceived efficiency gains in the utilization of labour. We estimate longer time employment risk, labour use adjustment and the efficiency of labour utilization in the Pakistani cement industry. We conclude that firms have made significant adjustments in labour use and employment risks have indeed reduced. Our estimates however, show that long run labour use efficiency in the industry and in the privatized firms has not improved, but that, surprisingly, firms set-up and operated privately have experienced a decrease in labour efficiency.
\end{abstract}

JEL classification: G21; G28; E24; J23

Keywords: Labour use efficiency; Privatization; Wage elasticity; Employment risk 


\section{Introduction}

Firms need to use their inputs at an efficient rate to maximize profitability and to remain in business under competitive conditions. Therefore, if a firm is using more labour in the production process than is technically required, it will be operating below the 'frontier' of efficiency. Policy makers and academics alike take a keen interest when these relative levels of inefficiency appear consistently. For a very long time period, state-owned enterprises (SOEs) all across the world generally were accused of employing more labour compared to what was optimally required. Broader reforms including the transfer of ownership from public to private sectors were mainly aimed at making these firms efficient in the utilization of inputs including the workforce. The job-loss fears at the time of privatization were widespread and well documented across the world. These fears were debated but ignored due to anticipated labour utilization efficiency gains after privatization.

After more than three decades of the aggressive use of privatization programmes as a policy to reform SOEs in developed and developing countries, there are very few influential empirical published studies that have investigated the impact of privatization and other broader reforms on the subsequent efficient use of labour by privatized firms, and how these firms have competed against those firms which were not privatized and remained in the public sector or firms which were already operating under private ownership or were set up later on. Those few empirical published studies of labour use efficiency have focused upon manufacturing, agricultural and lately banking industries (see Haouras et al 2003; Okten and Arin 2006; Liefert et al 2005; Kumbhakar and Hjalmarsson 1995; El-Gamal and Inanoglu 2005; Jaffry et al 2008; and Das et al 2006 on Tunisian manufacturing, Russian agriculture, Turkish manufacturing sectors, Swedish social security offices, the Turkish banking industry, and Indian subcontinent banking industries).

Of those studies that have examined privatization, layoffs and labour use efficiency, many focus on calculating and interpreting ratios such as profit per employee, assets per employee and the number of employees in the pre and post privatization/deregulation sub-periods. Also, this has 
to some extent been related to developed countries such as the Swedish banking sector (analysed by Battese et al 2000, Heshmati 2001 and Gjirja 2004) mainly due to data availability. As a result, detailed and sophisticated econometric analysis into labour use efficiency in the pre and post privatization periods for manufacturing sectors in a developing country has been relatively ignored.

This study seeks to fill this gap in the empirical literature of industrial organization by examining labour use efficiency in both the pre and post privatization periods in the Pakistani cement industry in response to privatization and other macro-economic reforms taking place over the course of the 1990s. Similar to worldwide thinking, these policies were designed to allow privatized firms to adjust their use of labour through layoff and the golden handshake schemes. The main objective of the latter or labour severance schemes introduced in the Pakistani cement industry was to bring selected employees out of their contracts in order to reduce the workforce to a more efficient/sustainable level and thus to become technically more labour use efficient. The other broader reforms, such as abandoning the practice of state institutions' role in setting output prices and the abolishing of inputs subsidies, were also aimed at making the industry more competitive. If firms were able to improve their labour use to a competitive level then they would have been successful in moving closer to the efficiency frontier in order to be able to survive the increased competitive pressures, which should result from increased levels of competition.

By considering the above-mentioned aims of reforms and privatization policy and related adjustments in workforce of the state owned firms, some obvious but interesting empirical questions arise. Did the management of privatized firms make economically justified adjustments to labour use? Did these reforms lead to long-run labour use efficiency gains? Did the initial reduction in workforce before privatization reduce the subsequent employment risks? Were these labour use adjustments and resulting anticipated efficiency gains of privatized firms comparable to other competitor privately owned firms? Was the contribution of reforms, and other factors 
such as macroeconomic conditions, and product demand conditions the same over a longer post reforms period in enhancing labour use efficiency or did some factors contribute relatively more?

Our study tries to answer the above mentioned questions by utilizing a two decades of post reforms and privatization data. We employ a panel data set, comprised of operational data from the Pakistani cement industry over the pre and post privatization periods (1986 to 2011). This study period represents 4-5 complete business cycles and should provide a comprehensive picture of adjustments in labour use in the post liberalization and privatization period. Specifically, a majority of similar type studies mentioned above have not used a data set that encompasses the full range of a significant period of reform. Furthermore, the choice of cement industry as a case study is interesting one due to its contribution in employment generation, tax collection and more importantly its relatively high propensity of being subject to allegations of collusions and cartel practices worldwide. The Pakistani cement industry has also been under intense scrutiny since the privatization in early 1990s and provides an interesting setting to see that rents due to alleged illegal practices were shared with workers or not which is often anticipated in industrial organization literature.

Five important conclusions could be drawn from our empirical estimates. First, firms responded in their demand for labour to changes in output, wages and capacity levels. Second, labour demand became less responsive to changes in the wage rates in the later period of the sample period. Third, employment risk has come down significantly over time and in particular from 1997 to 2011. The variable 'wages' is the most crucial factor contributing to the risk of employment but this wage related risk has come down since the initiation of reforms in 1991/92. Fourth, overall median labour use technical efficiency is $87 \%$, and private firms becoming relatively less efficient in terms of labour usage, followed by public firms since 1997. Fifth, our multivariate regression to find the determinants of labour use efficiency, confirms that after controlling firm size, production technology, levels of working capital, exporting experience and geographical location of the firm, privatized firms did outperform competitor firms that were set up and operated by 
the private sector. This cannot be said of those firms that remained under public ownership during our sample period.

The rest of the paper is comprised of six more sections. Section 2 discusses the main developments and reforms in the Pakistani cement industry alongside the current state of play. The next section is comprised of the methodology in terms of basic theory and concepts, specification of an empirical model and estimation strategy. Data requirements and sources are discussed in section 4. Section 5 contains empirical findings and the last section (section 6) summarizes the main conclusions.

\section{Broader Reforms and Privatization in the Pakistani Cement}

\section{Industry}

Cement manufacturing is a well-established industry in Pakistan, accounting for about $5.5 \%$ of total industrial production, representing 1.4\% of GDP and contributing 30 billion Rupees annually to the national exchequer. In January 1972, the cement industry was nationalized, and all the firms were placed under the Board of Industrial Management (BOIM). At the beginning of the financial year, 1986-87, the Pakistani cement industry consisted of 17 firms, with an aggregate nominal installed capacity of 7.7 million tonnes per year (tpy). Thirteen of the firms, comprising about 6.0 million tpy ( $78 \%$ of total capacity) belonged to a government holding company called State Cement Corporation (SCCP) and the remaining 4 firms with installed capacity of 1.63 million (tpy) were operating under private ownership. Since then, new private firms had entered the market and some older firms have been acquired by competitors.

The partial privatization of the state owned cement manufacturer firms commenced in 1984, when the first attempt was made by SCCP to divest part of its shares in Zeal Pak and Gharibwal Cement through the enterprise mutual fund of the Investment Corporation of Pakistan (ICP). Shares worth Rs.30 million were sold by SCCP to ICP at market price, which subsequently sold them without any difficulty, as part of a mutual fund to the public. In 1992, cement companies 
like Dandot Cement, D.G. Khan Cement, Kohat Cement, Maple Leaf Cement, Gharibwal Cement, White Cement and Zealpak Cement were privatized. Out of the 8 firms privatized in the period 1991-92, six were sold to established industrial groups, which already had experience managing industrial units in Pakistan and the remaining 2 firms were sold to 'Employee led Groups".

At the time of privatization of these firms, the total numbers of employees working in different fields were 5,520. The government, prior to the privatization of cement producing firms, implemented a 'golden handshake' or severance scheme for the workers. The response from workers was encouraging, and some $20-30 \%$ of workers opted for the scheme. The government required a payment of $40 \%$ of the bid value at the time of the transfer of ownership. This amounted to Rupees 2,297.19 million at that time, and a further 2,860 million was to be paid at a later date. The privatization process for Thatta Cement and Mustehkam Cement was also completed at that time although payment was delayed, and finalized later after court cases. The privatization of Associated Cement, Rohri and Wah and General Refractors was completed in 1996 and Javadan and Mustehkam Cement in 2003-06.

The industry has made a significant step forward since the initiation of transfer of ownerships of state owned firms in 1991-92. A number of new private firms have entered and some private sector firms have either ceased their operation or have been merged with larger manufacturers. The majority of these new and old firms have listed their shares on the stock exchanges, thus boosting the market activity. The industry has started exporting a large quantity of cement to neighbouring countries and Middle East and contributions to state exchequer in the forms of direct and indirect taxes and foreign exchange earnings is on the rise.

\footnotetext{
${ }^{1}$ Companies owned and operated by their employees themselves, sometimes known as co-operative enterprises.
} 
Despite these positive developments, the industry has been accused of running cartels/collusions and manipulating prices and supply immediately after the start of privatization and subsequent setting up of producers association. There have been a number of court cases and investigations by the regulatory authorities. Interestingly, allegation of collusion practices are similar to a worldwide trends for this industry. The producers association however have maintained that cooperation among firms is to ensure demand and supply match and stability in prices. Thus, the findings of this paper shall shed some light on the impact of perceived increased revenues on employment risks and wages if these allegation of collusions are considered to be true. This angle of the research shall make a significant number of readers interested from a number of countries from developing and developed where cement manufacturers have been accused of forming and running cartels.

\section{Methodology}

\subsection{Conceptual framework}

By following Heshmati (2001) and Bhandari and Heshmati (2005) and extending the basic framework to allow for specific industry and economic/operational environment, the demand for labour by the firm is expressed in terms of the input requirement function of Diewert (1974) as:

$$
\begin{gathered}
h=f(y, w, q, z, t) \exp (\epsilon) \\
\varepsilon=\mu+v
\end{gathered}
$$

Where $h$ is units of employed labour by firm measured in terms of hours worked, $f$ represents the production technology of the firm, $y$ represents firm output using labour, $w$ is the hourly wage rate, $q$ represents fixed assets (a proxy for capital), and $z$ represent the firm's heterogeneities in terms of the production technology constraints (firm employing advanced (dry) or old (wet) process production technology represented by (age) of the firm, as older firms were more likely to use the older wet process in our case), learning by exporting (firm is exporter), and 
type of ownership (firm is state owned). More specifically, we aim to capture heterogeneity in labour input requirement by including three variables i.e. a dummy variable equal to one for exporter firm, log of age of the firm and the dummy variable equal to one if the firm belongs to the public sector.

Age could be a proxy of vintage technology as well as an accumulation of experience over time. The dummy variable public ownership represents the constraint of historical baggage of operating in a somewhat less competitive environment with excessive employment enforced upon by government for political gains. Production and cost advantages, due to the acquiring of knowledge by competing in the international export market are well documented and we hope to differentiate firms by exporter status dummy variable. Finally, $\mathrm{t}$ represents the time effect in the form of the time dummy variables that could also act as a proxy for technological progress.

Overall, the above function (1) represents the production possibility frontier subject to given level of $h$. More specifically, this function estimates the minimum amount of labour required to produce a given level of output. The error term $\varepsilon$ is decomposed into two separate parts $(\mu$ and $v$ ) as per the seminal paper by Aigner et al (1977), representing technical efficiency $\mu$ and factors beyond the control of firm $v$ (such as seasonal variations in output demand, change in government policies and political unrest, etc.). In addition to these two factors, the firms' production technology will also have an impact upon their demand for labour. If the $\mu$ component of the error term for any observation is greater than zero, the firm displays a level of technical inefficiency in labour use, meaning that the individual firm has used more labour than was technically the minimum necessary in order to produce a given level of output. A firm, which displays a $\mu$ value of zero, can claim to be fully efficient in the use of labour. The $v$ component of the error term can be both positive and negative (i.e. those factors which are not in the control of the firm could have a positive or negative effect on the firm demand for labour and operational efficiency). It is worth mentioning that due to the presence of $v$, the labour demand frontier is stochastic even when $\mu$ is set to zero. 
We could extend the above function (1) by including employment variance (risk) in the labour requirement functions by following the work of Just and Pope (1978). We would like to refer to Heshmati (2001) for more detail on the extension of the stochastic component of equation (1). By doing so, equation (1) then becomes:

$$
h=f(x ; \alpha) \exp (g(x ; \beta) \varepsilon)
$$

Where the first part, $x=(y, w, q, z, t)$, with $f(x ; \alpha)$ representing the demand for labour part, and the second, representing the employment variance component of the labour demand function. By following other similar studies, the model can also be re-specified in log linear form as:

$$
\ln h=\ln f(x ; \alpha)+g(x ; \beta) \varepsilon
$$

Heshmati (2001) derived the expected value and variance of the above function (3) and subsequently derived and discussed the implication on marginal variance (risk) effects with respect to output and inputs (see page 426 of the above mentioned paper for details).

\subsection{Empirical estimation strategy}

We chose output and inputs in accordance with the existing literature. The specific variables used in the empirical analysis include the total quantity of labour hours used (h), output (y) measured by quantity of cement produced and sold, the hourly labour wage rates (w), capital (q), age of the firm (years since operation), a public sector firm dummy variable, an exporter dummy variable and time dummies representing exogenous rates of technological change $(\mathrm{t})$. Nominal monetary values are converted into constant 2001 prices. The 'wage' variable is defined as hourly wages - an aggregate measure of the cost associated with the hiring of labour, including payroll taxes. The quasi-fixed asset variable, q (capital), is representative of the production capacity constraints. 
The translog regression model outlined below was subsequently estimated on the population of the Pakistani cement manufacturing firms. In common with similar studies such as Jaffry et al (2008), a flexible translog functional form is used to approximate $f($.$) and g($.$) . Following Jaffry$ et al in the case of the subcontinents banking industries, we estimate common labour demand and efficiency irrespective of ownership types, area of operation, and size of the firm over both pre and post privatization time periods. The translog labour demand model can be specified as:

$$
\begin{aligned}
& \ln h_{i t}=\alpha_{0}+\alpha_{y} \ln y_{i t}+\alpha_{w} \ln w_{i t}+\alpha_{q} \ln q_{i t}+\lambda_{t}+\delta_{i}+\frac{1}{2}\left\{\alpha_{y y} \ln y_{i t}^{2}+\right. \\
& \left.\alpha_{w w} \ln w_{i t}^{2}+\alpha_{q q} \ln q_{i t}^{2}\right\}+\alpha_{y q} \ln y_{i t} \ln q_{i t}+\alpha_{w y} \ln w_{i t} \ln y_{i t}+ \\
& \alpha_{w q} \ln w_{i t} \ln q_{i t}+\alpha_{p u b} \text { public }+\alpha_{a g e} \text { age }+\alpha_{\text {exp }} \text { exporter }+\left\{\beta_{y} \ln y_{i t}+\right. \\
& \left.\beta_{w} \ln w_{i t}+\beta_{q} \ln q_{i t}+\beta_{t}+\beta_{p u b} \text { public } i t+\beta_{a g e} \ln \text { age } e_{i t}+\beta_{\text {exp }} \text { exporter }_{i t}\right\}\left[\mu_{i t} v_{i t}\right]
\end{aligned}
$$

where $h, y w$ and $q$ are variables defined and discussed as above, $i$ is an index of sample firms $(i=1,2, \ldots, N), t$ represents an index of time $(t=1,2, \ldots, N)$. A vector of time dummies $\lambda_{t}$ (representing the exogenous rate of technological change) and firm dummies $\delta_{i}$ (representing heterogeneity across firms) are used alongside other variables. We do not assume that an inefficient firm would remain inefficient or that the same firms would act as an efficiency leader for many years. Hence, in order to accommodate the fact that the most efficient firm could change in each time period (sample year), time variant technical labour efficiency scores are calculated following Schmidt and Sickles' (1984) and Heshmati (2001) framework, where technical inefficiency (TINEFF) is derived such as:

$$
\begin{gathered}
\text { TINEFF }_{i t}=g\left(x_{i t} ; \beta\right)\left(\alpha_{0}+\mu_{i t}\right)-\min \left[g\left(x_{i t} ; \beta\right)\left(\alpha_{0}+\mu_{i t}\right)\right] \\
=\left(\beta_{y} \ln y_{i t}+\beta_{w} \ln w_{i t}+\beta_{q} \ln q_{i t}+\beta_{t}+\beta_{p u b} \text { public }_{i t}+\beta_{\text {age }} \ln \text { age }_{i t}+\right. \\
\left.\beta_{\text {exp }} \text { exporter }_{i t}\right)\left(\alpha_{0}+\mu_{i t}\right)-\min _{t}\left[\left(\beta_{y} \ln y_{i t}+\beta_{w} \ln w_{i t}+\beta_{q} \ln q_{i t}+\beta_{t}+\right.\right. \\
\left.\left.\beta_{\text {pub }} \text { public }_{i t}+\beta_{\text {age }} \text { ln age }_{i t}+\beta_{\text {exp }} \text { exporter }_{i t}\right)\left(\alpha_{0}+\mu_{i t}\right)\right]
\end{gathered}
$$


and relative labour use technical efficiency $(T E F F)$ is calculated as:

$$
T E F F=E X P\left(-T I N E F F_{i t}\right)
$$

A priori, we expect $\alpha_{y}$ and $\alpha_{q}$ regression coefficients of equation (4) to be positive and $\alpha_{w}$ negative, which are interpreted as the elasticity of labour demand with respect to: output, capital input and wages respectively. These expectations are mainly valid at the average data point, with the corresponding elasticities (which are both firm specific and time specific) outlined below:

$$
\begin{gathered}
E_{y}=\frac{\partial \ln h_{i t}}{\partial \ln y_{i t}}=\alpha_{y}+2 \alpha_{y y} \ln y_{i t}+\alpha_{y w} \ln w_{i t}+\alpha_{y q} \ln q_{i t} \\
E_{w}=\frac{\partial \ln h_{i t}}{\partial \ln w_{i t}}=\alpha_{w}+2 \alpha_{w w} \ln w_{i t}+\alpha_{y w} \ln y_{i t}+\alpha_{w q} \ln q_{i t} \\
E_{q}=\frac{\partial \ln h_{i t}}{\partial \ln q_{i t}}=\alpha_{q}+2 \alpha_{q q} \ln q_{i t}+\alpha_{y q} \ln y_{i t}+\alpha_{w q} \ln w_{i t}
\end{gathered}
$$

Similarly, time specific elasticity of labour demand with respect to time (the exogenous rate of technological change) is derived as:

$$
E_{t}=\frac{\partial \ln h_{i t}}{\partial t}=\left(\lambda_{t}-\lambda_{t-1}\right)
$$

By using equation (7), return to scale could be calculated as $\frac{1}{E_{y}}$. For further detailed explanation of this methodology and empirical estimation framework, we encourage reader to consult Heshmati (2001) study. 


\section{Data}

Historical data on cement output, input quantities (values), cement prices and firms' characteristics were obtained through company annual reports, site visits, interaction with government ministries, personal contacts and telephone interviews with concerned regulatory authorities and the All Pakistan Cement Manufacturers Association (APCMA). The final panel data set used in this paper comprises data from the period 1986 to 2011 for the public, privatized and private sector firms. Our data set is comprised of firms covering $98 \%$ of the industry in the pre and post privatization time periods. More importantly, due to the very long nature of the post privatization sample period (two decades), we are able to evaluate the longer-term impact of broader reforms including privatization on industry labour demand, adjustments and efficiencies. As discussed before, this study is unique on this issue as far as we are aware. We eliminated less than $1 \%$ of observations due to unexpected values (outliers) before the estimation stage. The panel is unbalanced as not all firms were in existence throughout the sample years covered by this study. Many private firms only began their operations after 1991. Summary statistics of the data are presented in Table 1 below.

[nsert Table 1 about here]

\section{Estimation and Explanation}

The first step in our estimation strategy of the model presented in Equation (4) is to determine the labour demand function for Pakistani cement manufacturing firms. Table 2 contains estimates of the demand function, $(f)$ and the variance function, $(g)$. We estimated variance function ( $g$ ), discussed and outlined above, by using the weighted non-linear method. The majority of the firm specific variables are statistically significant and hence different from zero. These regression estimates are subsequently used to calculate firm and time specific elasticities of labour demand with respect to outputs, wages and capital (fixed assets). 


\section{[Insert Table 2 about here]}

Table 3 contains median values of elasticity estimates by firm characteristics such as size and ownership types as well as by time periods. Size categories of firms are based on the average number of full-time employees. We classify a firm as very small if it employs less than 300 employees, small with 301 to 500, medium with 501 to 700 , large with 701 to 900 and very large for employing $>900$ employees. These estimates reveal that, except for wage and time trend, all elasticities are positive at the median data point. This indicates that firms did respond in their demand for labour to changes in the output, wages and capital levels. The labour demand elasticity with respect to the output is positive for all sizes of firm (extremely small, small, medium, large and very large). This is also true of the three ownership categories (public, private and privatized) firms. All these findings are as per our expectations. The output median elasticity of 0.32 is not very low and had steadily increased over time suggesting that firms maintained their intensity of labour use over time. We could also infer from this estimate that the degree of elasticity is very unlikely to be significantly different across the number of firms included in the sample, thus exhibiting a marginal change in output will have a significant marginal effect on labour demand.

The sign of the wage elasticity variable is consistent with theory too, and the temporal pattern of change indicates that labour demand is becoming cyclical and less responsive to changes in the wage rates in the later period of the sample period. Interestingly, the magnitude of -0.180 is the largest of the input elasticities. The yearly estimates also indicate that the wage elasticity increased immediately after deregulation (increasing from -0.068 in 1986 to -0.30 in 1995). Hence, it implies that further reduction in the workforce would prove relatively difficult due to the nonavailability of skilled labour during the high demand period when demand for cement goes up due to good economic growth or an increase in export potential to neighbouring countries and 
the Middle East (two of the main export markets in the last few years when some firms exported a large quantity of cement to Afghanistan and UAE.).

\section{[Insert Table 3 about here]}

Contrary to wage elasticity, the elasticity with respect to capital is estimated with less precision with a median value of -0.06 . There is a clear trend in the elasticity, initially starting at -0.024 in the first year of the sample (1986) and ending at -0.115 in 2010-11. This temporal pattern indicates a decreasing demand for labour with an increase in the book value of assets (capital). The negative sign is also an indication of capital being substituted for labour. The use of more capital is an indication of the modernization of the production process which in turn would require less labour. The sample median value of technical change (consisting only of neutral component changes) over time is -0.05 , indicating some positive technical progress (a slight decrease in labour usage over time). Technical change fluctuates from positive to negative with a negative trend established for many years at a time indicating consistent positive technical development during those years. This technical progress is similar to the conclusions in Ghulam and Jaffry (2015) and as expected due to a massive investment by producers on production technology upgrade and capacity additions.

The magnitude of output elasticities seems to vary with the size of the individual firm in the sample. The labour demand elasticity with respect to wages seems to increase as firm size increases. This suggests that increased wage levels do not constitute a strong barrier to the hiring of additional labour for larger firms, as opposed to their smaller counterparts. This could be due to the fact that larger size firms would still keep a higher number of workers to meet higher output demand in future despite an increase in wage rates. The elasticity, with respect to output, does not decrease with firm size, showing that larger firms are in a better position to expand their output without having a large impact on their labour demand. The labour demand elasticity with respect to capital seems to fall with the size of the firms, indicating that growth in capacity 
alongside moving to new technology requires less additional labour for larger firms. Finally, the time trend shows a remarkably consistent pattern of technical progress irrespective of the size of firm, showing that this progress, shown over the sample period, has not been largely limited to firms of a specific size.

In terms of elasticities differentiated by ownership of the firm, different ownership firms have similar labour demand elasticity with respect to output, but significantly less than one. This is expected, given the fact that the firms have already quite significant salaries bills in their overall cost structure and further expansion is likely to lead to some reduction in employment.

Following Heshmati (2001), one of the advantages of our estimation strategy is that we could estimate employment variance (risk). The second part of Table 2 contains parameter estimates of this employment variance function. The estimates show that the beta coefficient with respect to output is positive and statistically significant. Interestingly, the wage coefficient, although positive, is statistically insignificant. The same is the case for exporter firms too. For all other variables such as for capital, time trend, public sector firm dummy and age of the firms, variance coefficients are positive and statistically significant. Subsequently, by using estimates presented in Table 2, we calculate the employment variance elasticity or marginal risk effects with respect to the dispersion factors of 'output', inputs ('wages' and 'capital') and 'time trend'. We calculate median values separately for each time period, and ownership types and these values are reported in Table 3.

The marginal employment variance (risk) effect evaluated at the median of the data with respect to 'output', is positive in both pre and post reform periods. It implies that any sample firm that is producing levels that are close to the sample median, the employment variance would increase if that firm produces more output. But interestingly, this employment risk has come down significantly over time and in particular from 1997 to 2011. It probably also indicates that further adjustment to employment would not be possible, given the replacement of old technology with 
a newer model and adjustment in employment may have already taken place in earlier periods. For public firms, this employment risk is the largest however negative. For capital, this is also true irrespective of the ownership type and the time period. The variable 'wages' is the most crucial factor contributing to the variance of employment in terms of marginal effects. Interestingly, the employment risk with respect to wages has come down since the initiation of reforms in 1991/92. Significantly, more variations in the estimated marginal effects seem to take place as firm size increases.

Equation 6 is used to estimate individual firm level labour use technical efficiency for each time period. This is a relative measure of firm performance in a particular year as it is relative to the best performing firm in that year. The best (benchmark) firm is supposed to be $100 \%$ efficient. The frequency distribution of technical efficiency is reported in Figure 1. A significant number of firms are found in the intervals of between $80 \%$ and $90 \%$ labour utilization efficiency scores. Starting with industry performance in terms of utilization of labour, the overall median technical efficiency is $87 \%$. It means that on average, the industry, without any reduction in output, could have reduced labour usage by $13 \%$. Nonetheless, this is indicative of a relatively high level of median labour use efficiency and similar to that observed by Heshmati (2001) in the study of Swedish savings banks. It is extremely high, when compared with that observed in the Tunisian banking sector study by Chaffai (1997). On the other hand, these estimates also indicate that the differences between top and low performer firms are relatively small.

[Insert Figure 1 about here]

Interestingly, labour use efficiency estimates also reveal that there appears to be no obvious difference in technical efficiency scores between firms of different sizes with the exception of medium size firms. The estimates indicate that the largest firms could reduce their labour demand on average by around $9 \%$ without reduction in efficiency, with the smaller firms only requiring around an $8 \%$ reduction at the median. Therefore, there is a remarkably narrow gap between the 
optimal level of labour efficiency and that which is observed by the firms. Similarly, among firms of different ownership types, the efficiency estimates indicate that private firms are relatively less efficient in terms of labour usage, followed by public firms. Private firms could have reduced their labour usage by roughly $17 \%$, public by $11 \%$ and privatized by only $9 \%$. Hence, private firms were employing far more labour than is technically necessary given output levels, hence, this group of firms has some way to go before significantly improving labour use technical efficiency levels.

\section{Further analysis of temporal patterns in elasticities and efficiencies by ownership}

Firm specific labour use efficiencies and elasticities of labour demand with respect to output, wages, capital and time trend are calculated and median estimates presented in Table 4 by significant time periods and ownership types. We divide the post privatization time period into two sub-periods. The period 1992-96 covers the immediate impact period of the start of the privatization programme and 1997-2011, the longer-term impact of the policy. The period 198691 is comprised of a pre privatization time span. Table 4 also contains estimates of the overall post privatization time period (1992-2011) for the sake of comparison.

Some interesting observations can be made by looking at these median estimates over significant time periods. Public sector firms, before their eventual privatization, become less labour responsive after 1992. Elasticity of output for public sector firms was reduced from 0.479 in 1986 to 0.36 in 2003 . These estimates were in fact 0.516 and 0.440 for the periods $1986-91$ and 19972011. However, there was no change for the immediate post reforms period. The estimates for the 1997-onward time period, however, should be interpreted with some caution because there were only two firms left under public ownership from 1997 (Mustehkam and Javeden). Contrary to public sector firms, output elasticities of privatized firms did not change over the entire post reforms period (1992-2011) compared to pre reforms period of 1986-91 (marginally increasing from 0.51 to 0.53$)$. Nonetheless, privatization and broader reforms did not have any significant effect on the employment response, for these firms. Interestingly, output elasticity for private 
firms significantly increased from 0.41 during 1986-91 to 0.57 during 1997-2011 with no immediate impact (1992-96).

[Insert Table 4 about here]

When it comes to labour adjustment in response to wages, the elasticities pattern over time reveals some interesting trends. Immediately after reforms, firms responded in accordance to predictions and wage elasticity kept rising until 1997. But then, afterwards, it came down for privatized as well as private sector firms. More specifically, these estimates for publically owned firms show a significant increase during 1992-96 compared to 1986-91 (-0.10 to -0.27$)$ but have come down from 1997- onward (-0.12 during 1997-2011). For privatized firms, these estimates increased from -0.10 to -0.20 immediately after privatization of these firms and settled at -0.15 during 1997-2011. By 1998, firms would have made changes in their labour usage and the shedding of additional workers would have been damaging to the long-term competitiveness of the firms. Interestingly, private firms experienced the highest increase from a mere -0.02 during 1986-91 to -0.23 during 1997-2011 (a tenfold increase and higher than other firms).

The intensity of the relationship between labour demand and capital is relatively weaker over the shorter as well as longer post reforms periods but interesting nonetheless. The elasticity estimates presented in Table 4 reveals that, for publically owned firms, capital elasticity increased from 0.02 during 1986-91 to -0.06 during 1992-96 but has been almost zero since then. For privatized firms, this elasticity increased from -0.02 during 1986-91 to -0.06 during 1997-2011. Again, more interestingly, for private firms, estimates show the highest increase from a mere -0.02 to -0.10 during longer post privatization time periods.

Table 4 also contains the median values of labour use technical efficiency scores by different time periods and ownership types. What is disappointingly apparent from investigating the changes in labour use efficiency over time is that median technical efficiency is continuously decreasing over 
time (see Figure 2). For example, in 1986 (the year our investigation started), the median firm achieved $88 \%$ labour use efficiency, compared with $77 \%$ in the final year of the sample period (11\% reduction). The yearly trends indicate that year on year negative change has been largest in the last fourteen years (1998 to 2011). Whether this was a result of the reforms, including privatization, needs further investigation. All this could have easily translated into higher prices of cement or reduction in margins during this period. Additionally, firms would have suffered losses too as a result of falling efficiencies. Ahluwalia (2002) suggests that a failure to live up to the full potential of privatization might not be down to changes in policies themselves, but a failure to implement these policy changes correctly. It may be that better implementation of the privatization policy will enable the median firm in the sample to move closer to the efficiency frontier in the years to come.

[Insert Figure 2 about here]

Interestingly, among firms of different ownership types, the efficiency estimates indicate that private firms were relatively less efficient in terms of labour usage before and after the reforms, compared to public firms (current and former). Hence, private firms were employing far more labour than is technically necessary given output levels. This group of firms also experienced the highest level of efficiency decline from 1997 to 2011 compared to the 1986-91 period (81\% compared to $87 \%$ ). Hence, this group of firms has some way to go in improving technical efficiency levels. Further, the efficiency estimates presented in Table 4 show that the group of public sector firms (current and former) were unable to improve their labour use efficiency over time. Initial efficiency gains (during 1992-96) were lost quickly and the overall trend appears to show no change compared to 1986-91.

\section{Determinants of labour use efficiency}

Firms' labour use efficiency could have changed due to a variety of reasons rather than privatization and other broader reforms only. Hence, in order to perform a more detailed analysis of the above findings, and similarly to Jaffry et al (2008) and other studies, a second stage 
regression was run in order to model a variety of other factors against the firm specific efficiency scores obtained and discussed in the previous section. In order to check for robustness in the estimates, five different specifications (which we refer to as model_1 - model_5) are estimated, with each involving the inclusion and exclusion of certain variables. The efficiency scores range from zero to one and hence, some studies have used Tobit regression to model determinants of efficiency. But, a few authors have quite recently advocated using simple OLS. We follow those studies and, due to the panel nature of our data, use a random effect regression model. Random effect regression is performed due to the fact that we do not assume that unobserved heterogeneity among different ownership firms is constant over time due to each firm behaving differently to changes in the economic, regulatory and market environment subsequent to reforms. The Hausman test of random versus fixed effect model confirmed this assumption.

We specify our base model (model_1) by including variables representing firm size, production technology (advanced/old), ownership type (public, private and privatized), exporter status (if the firm has exported to neighbouring countries and the Middle East), profitability and productivity, working capital ratio, and ratio of overheads expenses to total expenses. We use the log of total assets as a proxy for firm size that would also take into account significant capacity addition by privatized as well as privately owned firms in the post privatization time period. The quality of the management is approximated by general and administrative expenses (overheads) as a $\%$ of total cost. Similarly, more profitable firms could hire less but use only quality labour. Profitability in this case is measured as a return on assets. There could also be a trickledown effect of other inputs productivity. We use total factor productivity as a measure of other inputs' quality and productivity. We follow Galal et al (1994) to measure firms' total factor productivity. Availability of working capital could help routine inspection and maintenance of machinery and equipment.

To accommodate the learning by exporting element, we include a dummy variable equal to ' 1 ' if the firm is an exporter and ' 0 ' otherwise. The impact of superior technology is considered by adding a dummy variable equal to '1' for a firm using the dry (advance) production process. The 
proximity to export market and input sources is taken into account by a dummy variable equal to ' 1 ' for firms operating in the Pakistani northern region. Ownership effect is considered by adding two dummy variables for public and privatized firms. Finally, yearly dummies are added in these regression models to observe the impact of the post privatization time period on labour use efficiency.

The output from these five regression specifications is displayed in Table 5. Interestingly, the sign and significance of the variables do not seem to change dramatically between the five model specifications, highlighting that the model estimates are consistent and robust. After controlling for other firm specific factors, total assets have a positive and statistically significant coefficient, indicating that firms with larger assets (hence higher production capacity) tend to be more efficient in their use of labour. This result is an indication of potential scale economies. This could also be due to having the financial muscle to hire fewer in numbers but better quality production and administration/marketing workers. Firms spending more money on administration and marketing campaigns tend to be less efficient in their labour use. Having access to a higher level of working capital does not appear to have any significant effect on labour use efficiency. Financially profitable as well as productive firms (indicated by return on assets and total factor productivity variables) were on average using labour more efficiently.

\section{[Insert Table 5 about here]}

Change of ownership from public to private (privatized in our case) has a positive impact on efficiency. This is consistent with other studies indicating an improvement after change of ownership. Hence, a reduction in workforce prior to selling these state owned firms had made these firms comparatively more efficient in particular compared to firms operating under private ownership. The variable, reflecting public sector ownership, does not appear to have consistent estimates in term of signs and statistical significance across the five different models. These firms experienced a decline in their labour use efficiency compared to firms operating in the private sector at least in our two specifications. Contrary to expectations, operating in the Pakistani 
northern region with proximity to raw material and export market as well as using dry process technology appear to have a negative effect on labour use efficiency. Interestingly, exporter firms do not appear to have any advantage in term of labour utilization.

Our regression estimates of yearly dummies, after controlling the firms' specific factors mentioned above, supports the contention that the reforms had some positive effect initially (1992-97) but the trend has reversed in the later years of our sample period (2002 onward) and hence reforms have not encouraged firms to use labour more efficiently in the longer time period (with 2004-onward coefficients negative and statistically significant). This could be predominantly as a result of a relatively disappointing performance by public and private firms as discussed above.

\section{Robustness check}

In an effort to make sure that our findings are robust with respect to the different specifications of the labour demand function and influential observations of the data set used in this study, we carried out three robustness checks. These include: adding a new input variable (cost of capital approximated by depreciation cost), adding a time trend variable and its interaction with capital and output variables to incorporate the role of technological effect more specifically and dropping $1 \%$ more outlier observations. We do not report the results of these exercises here but generally speaking, these tests do not alter the main findings of our study qualitatively in terms of labour use efficiency estimates and other statistics discussed above.

\section{Conclusion}

A widely accepted view in the early 1980s was that state-owned firms were using more workers compared to optimal levels for these firms and were less efficient in their overall input use including labour. Privatization and other broader reforms were aimed at reducing inefficiencies in input usage despite fear of widespread job losses as a result of the transfer of ownership from the public to private sector. There has been a constant flow of studies examining the impact of these 
reforms on the financial and operational performance of privatized firms since the early 1980s when privatization policies were introduced in developing and developed countries. However, surprisingly, studies on the impact of reforms on labour use adjustments and efficiencies are few and less debated. The majority of the studies on labour use efficiencies using advanced econometric methods are not only few but mainly related to developed countries.

Our study fills this gap and we analyse the long-term impact of privatization and other broader reforms introduced in 1992 on labour use efficiency and adjustments of the Pakistani cement industry. The choice of the cement industry in this regard is not only interesting and relevant for developing country such as Pakistan due to significant contribution in tax collection and employment generation but it has an international relevance too due to worldwide allegations of illegal practices such as collusions and cartels formation by cement manufacturers. Our sample of 21 firms comprised of three ownerships: public, private and privatized covering the pre reforms period of 6 years (1986-91) and the two decades post reforms period (1992-2011). We believe that the coverage of post reforms period is the longest so far to explain longer run labour use adjustments and efficiencies after reforms and change of ownership.

By following Heshmati (2001) and similar to a cost function estimation, we estimate the labour demand function where the demand for labour is a function of wages, output, a quasi-fixed input (capital) and a time trend. We also include a number of other variables to account for firms' heterogeneity in terms of age, technology, ownership types and exporting experience. Subsequently, we compute employment risk (variance), inputs/output labour demand elasticities and firm level labour use technical efficiencies.

The magnitudes and signs of estimated input/output elasticities of the sample firms are broadly as expected. We observe that the largest labour demand elasticity is linked to wages. In terms of the temporal patterns of these elasticities, output elasticity increased significantly for private firms during 1997-2011 while, in comparison, there has been no such change for competitor privatized 
firms. Wage and capital elasticities have also increased for private firms but this is also true of privatized firms. However, the magnitude of change is comparatively higher for private firms as compared to other ownership firms. The estimation of employment variance reveals that any sample firm that is producing levels that are close to the sample median, the employment variance would increase if that firm produces more output. But interestingly, this employment risk has come down since 1997. The workers' wages appear to be the most crucial factor contributing to the risk of employment but again employment risk has come down since the initiation of privatization in 1991/92. Interestingly, employment risk seems to increase as firm size increases.

The conclusions with regard to the level and trend in labour use technical efficiencies are very interesting and informative. There appear to be comparatively fewer variations in the efficiency levels of different ownerships and size firms. It was found that, broadly speaking, a median firm could have reduced its labour usage by $13 \%$, without reduction in output. Interestingly, the initial impact of reforms was positive (in the first five years) for all firms irrespective of ownership. But since then there is no significant difference between pre and post reforms efficiency levels for publically owned and privatized firms. Surprisingly, private sector firms, however, experienced some decline in labour use efficiencies from 1997 onward. These estimates indicate that the policies enacted in the early 1990s in helping state owned firms to reduce their labour usage at least had a neutral long term effect but positive when compared to competitor private firms. Put it mildly, reforms has helped the privatized firms not to further over utilize labour and thus reduce efficiency compared to their private or state owned counterparts. But strictly speaking, it would appear that the significant broader reforms, including privatization, could have helped some particular industries such as the financial sector (see Jaffry et al (2008) for instance) in reducing the extent of over-utilization of labour, but we are unable to say the same in the case of the cement industry in Pakistan.

\section{REFERENCES}


AIGNER, D. J., LOVELL, C. A. K and SCHMIDT, P. 1977. 'Formulation and estimation of stochastic production function models', Journal of Econometrics, 6, 21-37.

AHLUWALIA, M. S. 2002. 'Economic reforms in India since 1991: Has gradualism worked?', Journal of Economic Perspectives, 16, 67-88.

BATTESE, E., GEORGE, HESHMATI, A., and HJALMARSSON, L. 2000. 'Efficiency of labour use in the Swedish banking industry: a stochastic frontier approach', Empirical Economics, $25,623-640$.

BHANDARI, A. K. and HESHMATI, A. 2005. 'Labour use and its adjustment in Indian manufacturing industries', Global Economic Review, 34, 261 - 290.

BONNACCORSI DI PATTI, B. and HARDY, D. C. 2005. 'Financial sector liberalisation, firm privatisation and efficiency: evidence from Pakistan', Journal of Banking and Finance, 29, 2381-2406. CHAFFAI, M. E. 1997. 'Estimating input-specific technical inefficiency: The case of the Tunisian banking industry', European Journal of Operational Research, 98, 314-331.

DAS, A. and GOSH, S. 2006. 'Financial reform and efficiency: An empirical analysis of Indian firms during the post reform period', Review of Financial Economics, 15, 193-221.

DIEWERT, W., E. 1974. 'Functional forms for revenue and factor requirement functions', International Economic Review, 15, 119-130.

EL-GAMAL, A., and INANOGLU, H. 2005. 'Inefficiency and heterogeneity in Turkish banking: 1990-2002', Journal of Applied Econometrics, 20, 641- 664.

GALAL, A., JONES, L., TANDON, P., and VOGELSANG, I. 1994. Welfare Consequences of Selling Public Enterprises (The World Bank, Washington, D.C.).

GHULAM, Y., and JAFFRY, S. 2015. 'Efficiency and productivity of the cement industry: Pakistani experience of deregulation and privatisation', Omega, 54, 101-115.

GJIRJA, M. 2004. 'Effects of deregulation and crisis on labour use efficiency in the Swedish banking industry'. Electronic Publishing Center Economic Studies, 136.

HAOURAS, I., YAGOUBI, M. and HESHMATI, A. 2003. 'Labour use efficiency in Tunisian manufacturing industries', Review of Middle-East Economics and Finance, 1, 195-214. 
HESHMATI, A. 2001. 'Labour demand and efficiency in Swedish savings firms', Applied Financial Economics, 11, 423-433.

JAFFRY, S., GHULAM, Y., and COX, J. 2008. 'Labour use efficiency in the Indian and Pakistani commercial banks', Journal of Asian Economics, 19, 259-293.

JUST, R. E. and POPE, R. D. 1978. 'Stochastic specification of production functions and economic implications', Journal of Econometrics, 7, 67-86.

KUMBHAKAR, S. C., and HJALMARSSON, L. 1995. 'Labour-use efficiency in Swedish social insurance offices', Journal of Applied Econometrics, 10, 33-47.

LIEFERT, W., LERMAN, Z., GARDNER, B. and SEROVA, E. 2005. 'Agricultural labour in Russia: efficiency and profitability', Review of Agricultural Economics, 27, 412-417.

OKTEN, C. and ARIN, K. P. 2006. 'The effects of privatisation on efficiency: how does privatization work?', World Development, 34, 1537-1556.

RAO, A. 2005. 'Cost frontier efficiency and risk-return analysis in an emerging market', International Review of Financial Analysis, 14, 283-303.

SCHMIDT, P. and SICKLES, R. C. 1984. 'Production frontiers and panel data', Journal of Business and Economic Statistics, 2, 367-374. 
Table 1: Descriptive statistics

\begin{tabular}{|c|c|c|c|c|}
\hline Variable & Mean & Std dev. & Minimum & Maximum \\
\hline hours (h) & 5127850 & 2963825 & 792000 & 18360000 \\
\hline output (y) & 0.73 & 0.86 & 0.00 & 6.55 \\
\hline wages (w) & 25.32 & 8.38 & 6.43 & 56.03 \\
\hline capital [fixed assets] (q) & 2528.22 & 2896.5 & 14.38 & 15140.4 \\
\hline time trend $(t)$ & 13.98 & 7.38 & 1.00 & 26.00 \\
\hline firm size ( 1 =very small, $2=$ =small, 3=medium, 4=large, 5=very large) & 3.5 & 1.09 & 1.00 & 5.00 \\
\hline firm type of ownership ( $1=$ public, $2=$ privatized, $3=$ private) & 2.17 & 0.79 & 1.00 & 3.00 \\
\hline firm age (years) & 24.9 & 12.63 & 3.00 & 57.00 \\
\hline
\end{tabular}


Table 2: Generalized Least Square (GLS) nonlinear regression parameter estimates of the labour demand and the employment variance function

\begin{tabular}{|c|c|c|c|c|c|c|c|c|c|}
\hline & $\begin{array}{c}\text { Parameter } \\
\text { estimate }\end{array}$ & $\begin{array}{l}\text { Approx. } \\
\text { std error }\end{array}$ & $\begin{array}{c}\mathrm{t} \\
\text { value }\end{array}$ & $\begin{array}{l}\text { Approx. } \\
\operatorname{Pr}>|\mathrm{t}|\end{array}$ & & $\begin{array}{l}\text { meter } \\
\text { mate }\end{array}$ & $\begin{array}{l}\text { Approx. } \\
\text { std error }\end{array}$ & $\begin{array}{c}\mathrm{t} \\
\text { value }\end{array}$ & $\begin{array}{c}\text { Approx. } \\
\operatorname{Pr}> \\
|\mathrm{t}|\end{array}$ \\
\hline \multicolumn{5}{|c|}{ a. labour demand function estimates } & \multicolumn{5}{|c|}{ b. employment variance function } \\
\hline constant & -1.163 & 0.434 & -2.680 & 0.008 & output (y) & 0.073 & 0.013 & 5.720 & .0001 \\
\hline output (y) & 0.869 & 0.059 & 14.850 & $<.0001$ & wages $(\mathrm{W})$ & 0.020 & 0.032 & 0.610 & 0.542 \\
\hline wages $(\mathrm{W})$ & 0.583 & 0.098 & 5.960 & $<.0001$ & capital (q) & 0.063 & 0.012 & 5.470 & 0001 \\
\hline capital (q) & -0.336 & 0.050 & -6.670 & $<.0001$ & time trend $(\mathrm{t})$ & 0.101 & 0.032 & 3.190 & 0.002 \\
\hline output*output $\left(y^{2}\right)$ & 0.292 & 0.037 & 7.860 & $<.0001$ & public firm (dummy) & 0.178 & 0.037 & 4.880 & .0001 \\
\hline wages*wages $\left(w^{2}\right)$ & 0.262 & 0.104 & 2.520 & 0.012 & exporter firm (dummy) & -0.013 & 0.040 & -0.330 & 0.738 \\
\hline capital*capital $\left(q^{2}\right)$ & -0.071 & 0.023 & -3.080 & 0.002 & firm age (years) & 0.054 & 0.011 & 4.790 & .0001 \\
\hline wages*output (wy) & -0.313 & 0.097 & -3.220 & 0.001 & & & & & \\
\hline output*capital (yq) & -0.152 & 0.041 & -3.690 & 0.000 & & & & & \\
\hline wages*capital (Wq) & -0.069 & 0.072 & -0.960 & 0.337 & & & & & \\
\hline public firm (dummy) & 0.156 & 0.067 & 2.340 & 0.020 & & & & & \\
\hline exporter firm (dummy) & -0.414 & 0.055 & -7.510 & $<.0001$ & & & & & \\
\hline firm age (years) & 0.567 & 0.140 & 4.050 & $<.0001$ & & & & & \\
\hline
\end{tabular}

Notes: firm and time dummy estimates excluded to conserve space. All variables except dummies are in logs. 
Table 3: Median input/output labour demand elasticities and employment variance (risk)

\begin{tabular}{|c|c|c|c|c|c|c|c|c|c|}
\hline & \multicolumn{4}{|c|}{ a. labour demand elasticities } & \multicolumn{4}{|c|}{ b. employment variance (risk) } & \multirow[t]{2}{*}{ c. efficiency } \\
\hline & output & wages & capital & time & output & wages & capital & time & \\
\hline overall & 0.508 & -0.152 & -0.063 & -0.051 & 0.019 & 0.005 & -0.014 & -0.034 & 0.871 \\
\hline 1986-91 & 0.487 & -0.076 & -0.024 & -0.049 & 0.030 & 0.122 & -0.044 & -0.025 & 0.881 \\
\hline $1992-11$ & 0.518 & -0.199 & -0.074 & -0.055 & 0.018 & -0.219 & -0.009 & -0.034 & 0.841 \\
\hline $1992-96$ & 0.509 & -0.189 & -0.067 & -0.051 & 0.053 & -0.318 & -0.065 & -0.061 & 0.936 \\
\hline $1997-11$ & 0.556 & -0.209 & -0.094 & -0.059 & 0.002 & -0.057 & -0.006 & -0.024 & 0.834 \\
\hline public & 0.491 & -0.119 & -0.036 & -0.050 & 0.101 & 0.004 & -0.072 & -0.034 & 0.890 \\
\hline privatized & 0.520 & -0.173 & -0.066 & -0.055 & -0.001 & -0.025 & -0.012 & -0.030 & 0.911 \\
\hline private & 0.504 & -0.210 & -0.070 & -0.051 & 0.001 & 0.001 & -0.006 & -0.024 & 0.831 \\
\hline very small & 0.187 & 0.035 & 0.071 & -0.051 & 0.000 & 0.005 & 0.000 & 0.000 & 0.890 \\
\hline small & 0.512 & -0.287 & -0.064 & -0.055 & 0.007 & -0.090 & -0.007 & -0.011 & 0.920 \\
\hline medium & 0.478 & -0.196 & -0.057 & -0.050 & 0.015 & 0.023 & -0.023 & -0.033 & 0.832 \\
\hline large & 0.520 & -0.201 & -0.065 & -0.051 & 0.044 & -0.305 & -0.036 & -0.044 & 0.916 \\
\hline very large & 0.573 & -0.103 & -0.085 & -0.051 & -0.006 & -0.356 & -0.013 & -0.026 & 0.890 \\
\hline
\end{tabular}


Table 4: Input/output labour demand elasticities and labour use efficiency scores by selected time periods and ownership types

\begin{tabular}{|c|c|c|c|c|c|}
\hline & overall & $1986-91$ & $1992-2011$ & $1992-96$ & $1997-2011$ \\
\hline \multicolumn{6}{|c|}{ output elasticity } \\
\hline public & 0.493 & 0.506 & 0.456 & 0.505 & 0.440 \\
\hline privatized & 0.534 & & 0.534 & 0.566 & 0.512 \\
\hline Private & 0.469 & 0.412 & 0.494 & 0.410 & 0.569 \\
\hline \multicolumn{6}{|c|}{ wage elasticity } \\
\hline public & -0.129 & -0.100 & -0.160 & -0.274 & -0.120 \\
\hline privatized & -0.169 & & -0.169 & -0.203 & -0.152 \\
\hline private & -0.119 & -0.022 & -0.138 & -0.102 & -0.232 \\
\hline \multicolumn{6}{|c|}{ capital elasticity } \\
\hline public & -0.032 & -0.027 & -0.037 & -0.059 & 0.001 \\
\hline privatized & -0.063 & & -0.063 & -0.079 & -0.055 \\
\hline private & -0.056 & -0.017 & -0.076 & -0.031 & -0.103 \\
\hline \multicolumn{6}{|c|}{ labour use efficiency } \\
\hline public & 0.887 & 0.887 & 0.892 & 0.913 & 0.866 \\
\hline privatized & 0.898 & & 0.898 & 0.956 & 0.896 \\
\hline private & 0.836 & 0.870 & 0.828 & 0.925 & 0.813 \\
\hline
\end{tabular}


Table 5: Random effect regression results (dependent variable: labour use efficiency scores)

\begin{tabular}{|c|c|c|c|c|c|c|}
\hline variables & model_1 & model_2 & model_3 & model_4 & model_5 & model_6 \\
\hline size (log of assets) & $0.01316^{* * *}$ & $0.01787^{* * *}$ & & $0.02010^{* * *}$ & $0.01613^{* * *}$ & $0.01098^{* *}$ \\
\hline overheads /total cost & -0.00771 & $-0.40008 * * *$ & & $-0.41701 * * *$ & $-0.40884 * * *$ & $-0.53108 * * *$ \\
\hline return on assets & $-0.05220 * * *$ & $0.08841^{*}$ & $0.13890 * * *$ & $0.12085^{* * *}$ & $0.08208^{*}$ & $0.07719 *$ \\
\hline total factor productivity & $0.01360 * * *$ & $0.01902 *$ & $0.02810 * *$ & & 0.01346 & 0.01187 \\
\hline working capital ratio & $0.00657^{*}$ & 0.0063 & 0.00428 & & 0.00618 & 0.00274 \\
\hline production technology $=$ dry & -0.02599 & $-0.05904 * * *$ & $-0.07343 * * *$ & $-0.05672 * * *$ & & $-0.07380 * * *$ \\
\hline operating area $=$ north & $-0.07849 * *$ & $-0.06095 * * *$ & & $-0.05867 * * *$ & $-0.06837 * * *$ & \\
\hline firm is exporter & $-0.01197^{* *}$ & -0.0141 & & -0.01437 & & -0.00279 \\
\hline ownership = public & 0.03542 & 0.00245 & -0.02546 & 0.00146 & $-0.05353^{* * *}$ & $-0.03273^{*}$ \\
\hline ownership = privatized & 0.07696 & $0.05979 * * *$ & $0.04462 * * *$ & $0.05872 * * *$ & $0.09741 * * *$ & $0.03168^{* *}$ \\
\hline time period & $-0.00528 * * *$ & & & & & \\
\hline \multirow[t]{2}{*}{ Constant } & $0.83399 * * *$ & $0.76166 * * *$ & $0.82020 * * *$ & $0.77447 * * *$ & $0.72210^{* * *}$ & $0.80910^{* * *}$ \\
\hline & & \multicolumn{3}{|c|}{ yearly dummies } & & \\
\hline 1987 & & 0.03663 & 0.02167 & 0.04636 & 0.03971 & 0.04331 \\
\hline 1988 & & 0.04093 & 0.02978 & $0.04843^{*}$ & 0.04300 & 0.04663 \\
\hline 1989 & & 0.04487 & 0.03685 & $0.05385^{*}$ & 0.04651 & 0.0502 \\
\hline 1990 & & 0.04388 & 0.03923 & $0.05179 *$ & 0.04346 & $0.05061 *$ \\
\hline 1991 & & 0.04302 & 0.04518 & $0.05166^{*}$ & 0.04299 & $0.05024^{*}$ \\
\hline 1992 & & $0.06589 * *$ & $0.06233^{*}$ & $0.07552^{* *}$ & $0.07427 * *$ & $0.07345^{* *}$ \\
\hline 1993 & & $0.05340^{*}$ & 0.04671 & $0.06486 * *$ & $0.06394 * *$ & $0.06580^{* *}$ \\
\hline 1994 & & $0.05678^{*}$ & 0.04891 & $0.06710 * *$ & $0.06620 * *$ & $0.06985^{* *}$ \\
\hline 1995 & & $0.04841^{*}$ & 0.03532 & $0.06137 * *$ & $0.05885^{*}$ & $0.06162 *$ \\
\hline 1996 & & $0.05984 *$ & $0.06873 * *$ & $0.07350 * * *$ & $0.06922 * *$ & $0.07373 * *$ \\
\hline 1997 & & $0.06770^{* *}$ & $0.08210 * *$ & $0.08074 * * *$ & $0.07734 * *$ & $0.07696 * *$ \\
\hline 1998 & & 0.00845 & 0.02481 & 0.01797 & 0.02114 & 0.01498 \\
\hline 1999 & & 0.00325 & 0.01976 & 0.01335 & 0.01422 & 0.00947 \\
\hline 2000 & & 0.0125 & 0.02721 & 0.01877 & 0.01949 & 0.01758 \\
\hline 2001 & & 0.00551 & 0.02644 & 0.01093 & 0.0133 & 0.0123 \\
\hline 2002 & & -0.00171 & 0.00939 & 0.00815 & 0.00379 & 0.00632 \\
\hline 2003 & & -0.0064 & 0.00363 & 0.00166 & -0.00157 & -0.00055 \\
\hline 2004 & & -0.01588 & -0.00516 & -0.00796 & -0.01284 & -0.00887 \\
\hline 2005 & & -0.03196 & -0.01358 & -0.02598 & -0.02722 & -0.0195 \\
\hline 2006 & & $-0.05891^{* *}$ & -0.03911 & $-0.05184^{*}$ & $-0.05467^{*}$ & -0.04561 \\
\hline 2007 & & $-0.06488 * *$ & -0.04065 & $-0.06643^{* *}$ & $-0.06425^{* *}$ & $-0.05797^{*}$ \\
\hline 2008 & & -0.0443 & -0.02967 & $-0.05021^{*}$ & $-0.04868 *$ & -0.03767 \\
\hline 2009 & & $-0.05638^{*}$ & -0.04534 & $-0.05897 * *$ & $-0.05646^{*}$ & $-0.04754 *$ \\
\hline 2010 & & -0.04411 & -0.03316 & $-0.05200 *$ & -0.0461 & -0.03626 \\
\hline
\end{tabular}

